ORIGINAL ARTICLE

\title{
CONCEPTUAL DEFINITION OF THE EXCESSIVE LIQUID VOLUME NURSING DIAGNOSIS $(00026)^{*}$ \\ DEFINIÇÃO CONCEITUAL DO DIAGNÓSTICO DE ENFERMAGEM VOLUME DE LÍQUIDO EXCESSIVO (00026)
}

DEFINICIÓN CONCEPTUAL DEL DIAGNÓSTICO DE ENFERMERÍA VOLUMEN DE LÍQUIDO EXCESIVO (00026)

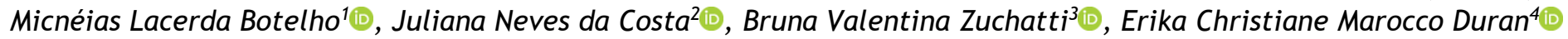

\section{ABSTRACT}

Objective: to construct the conceptual definitions of the components of the Nursing Diagnosis "Excessive Liquid Volume (00026)". Method: this is a bibliographic study, integrative review, between 2012 and 2016 in the databases MEDLINE, CINAHL and Web of Science. The PRISMA flowchart was used for identification, selection, eligibility and inclusion of studies. Data analysis was performed through thorough reading and understanding of elements that supported the elaboration of definitions. Results: 2,477 articles were found, 21 selected. One searched the gray literature, totaling 33 items. Conceptual definitions of the elements were constructed in the context of chronic renal patients. Conclusion: it will help, by the constructed definitions, in the recognition of the indicators that compose the phenomenon and in the planning of individualized care. In addition, the use of standardized languages, communication, patient safety and teaching. Descriptors: Nursing Classifications; Nursing Diagnosis; Nursing Process; Renal Insufficiency; Nursing; Validation Studies.

\section{RESUMO}

Objetivo: construir as definições conceituais dos componentes do Diagnóstico de Enfermagem "Volume de Líquido Excessivo (00026)". Método: trata-se de um estudo bibliográfico, tipo revisão integrativa, entre 2012 e 2016 nas bases de dados MEDLINE, CINAHL e Web of Science. Utilizou-se o fluxograma PRISMA para identificação, seleção, elegibilidade e inclusão dos estudos. Deu-se a análise dos dados a partir de leitura minuciosa e compreensão de elementos que subsidiaram a elaboração das definições. Resultados: encontraram-se 2.477 artigos, sendo 21 selecionados. Realizou-se a busca na literatura cinzenta, totalizando 33 itens. Construíram-se as definições conceituais dos elementos no contexto dos pacientes renais crônicos. Conclusão: auxiliar-se-á, pelas definições construídas, no reconhecimento dos indicadores que compõem o fenômeno e no planejamento do cuidado individualizado. Favorecem-se, além disso, a utilização de linguagens padronizadas, a comunicação, a segurança do paciente e o ensino. Descritores: Classificações de Enfermagem; Diagnóstico de Enfermagem; Processo de Enfermagem; Insuficiência Renal; Enfermagem; Estudos de Validação.

\section{RESUMEN}

Objetivo: construir las definiciones conceptuales de los componentes del Diagnóstico de Enfermería "Volumen Líquido Excesivo (00026)". Método: estudio bibliográfico, revisión integradora, entre 2012 y 2016 en las bases de datos MEDLINE, CINAHL y Web of Science. El diagrama de flujo PRISMA se utilizó para la identificación, selección, elegibilidad e inclusión de estudios. El análisis de datos se realizó a través de una lectura exhaustiva y la comprensión de elementos que respaldaron la elaboración de definiciones. Resultados: se encontraron 2.477 artículos, 21 seleccionados. Se realizaron búsquedas en la literatura gris, con un total de 33 artículos. Las definiciones conceptuales de los elementos se construyeron en el contexto de pacientes renales crónicos. Conclusión: ayudará, por las definiciones construidas, en el reconocimiento de los indicadores que componen el fenómeno y en la planificación de la atención individualizada. Además, se favorece el uso de lenguajes estandarizados, comunicación, seguridad del paciente y enseñanza. Descriptores: Clasificaciones de Enfermería; Diagnóstico de Enfermeira; Proceso de Enfermeira; Insuficiencia Renal; Enfermería; Estudios de Validacíon.

1,2,3,4Campinas State University. Campinas (SP), Brazil. 1D https://orcid.org/0000-0002-2806-9603 2(Dhttps://orcid.org/0000-0001-8505-2018 ${ }^{3 \text { (iD }}$ https: / / orcid.org/0000-0002-9288-3394 4 Dhttps://orcid.org/0000-0002-9112-752X

*Article extracted from the thesis << Clinical validation of the nursing diagnosis Excessive fluid volume (00026) in chronic renal patients >> State University of Campinas, 2019. 


\section{INTRODUCTION}

It is known that the Nursing Process (NP) is recognized as the work tool of nurses and it is through this that this professional can plan and implement qualified and effective care. It is informed that, over the years, laws guide the directions of professional practice and, above all, support and support Nursing actions so that the care provided is of quality and, above all, that the expected results are achieved. ${ }^{1-2}$

It is understood that, in order to favor the practice of nursing work, currently several initiatives subsidize their practice through methodologies that operationalize this process and contribute significantly to the improvement of expected results. It is added that the Standardized Language Systems (SLS) emerged with the intention of standardizing the vocabulary used by nursing, conferring scientific support to the decisions made by nurses, naming the elements of professional practice and assigning legitimacy to the profession, since the phenomena by nurses, which the professional is responsible for, are duly registered and appointed. ${ }^{3}$

The aim of the various SLS is to favor certain phases of NP, and the joint use of these terminologies enables nursing care in a single language, gives visibility of work and professional recognition, safety in planning and quality for care management. ${ }^{3}$ By such uniformity of vocabulary, a standardization of patient chart presentation is allowed.

It is believed that, for the Nursing Diagnosis (ND) phase, the classification of NANDA International Nursing Diagnoses (NANDA-I) is the best known and widespread in the various countries of the world. ${ }^{4}$

Among the ND presented by NANDA-I (20182020), two domain "nutrition", class five "hydration" stands out, the diagnostic concept Excessive Liquid Volume (00026) defined as "excessive intake and / or fluid retention". 5:186 It is a common ND in patients with chronic kidney disease $(C K D)^{6-7}$ and, knowingly, this human response has negative consequences for the patient's life, both in the subjective and objective spheres, caused by physical, psychological and social changes. ${ }^{8}$

Due to the impairment of regulatory mechanisms, the signs and symptoms that affect the patient's life result as, as the Glomerular Filtration Rate (GFR) decreases, the metabolic, hydroelectrolytic imbalance increases, leading to azotemia and uremia. ${ }^{9}$ These patients present numerous signs and symptoms that require nursing care based on the best available scientific evidence. In this context, it is up to the nurse, through the NP, to draw up a therapeutic plan aimed at solving or minimizing the problems presented by the patients and the imminent risks of severe complications that they may present, safely and effectively through the structured NP. ${ }^{7}$

The signs and symptoms presented by the patients are represented by the Defining Characteristics (DC) that make up each problemfocused ND. It becomes the accurate diagnostic process by the precise identification of these DCs, while a certain inference on the human response that actually reflects the patient's true condition in the environment in which care is provided, giving him the possibility of appropriate treatment. $^{10}$

The literature describes several difficulties reported by professionals in the diagnosis process. These include lack of time, excessive activity, excessive number of patients, lack of staff, staff awareness, knowledge and experience with the use of classification. In addition, in some situations, some common element NDs, such as Related Factors (RF) or DC, are difficult to establish, due to their accuracy. ${ }^{11}$

It is understood that a strategy that aims to minimize this problem is the content analysis and clinical validation studies that seek, through different methods, to confer legitimacy to the diagnostic process in specific populations. As studies in this field advance, there is a refinement of classifications through the identification of factors contributing to the occurrence of such an event, as well as signs and symptoms that best describe the responses of the human person, family or community health and disease processes. ${ }^{3}$ Throughout this process, the decisionmaking of nurses, the accuracy in choosing the ND that reflects the real situation of the patients cared for, as well as the improved communication between the team members through the Nursing registry is favored.

The initial stage of validation studies is the integrative literature review, which is the method used to construct the definitions of the elements that make up an ND. Instrument definitions are used for practice conduct as they describe the abstract or theoretical meaning of the concepts studied (conceptual definition) and specify the operations that researchers must do to collect information, indicating how the concept is found or measured in practice (operational definition) congruent with the conceptual definition. ${ }^{12}$

The objective of this study was to take into account the above, and taking into account the high number $(126,583)$ of people with CKD on dialysis in Brazil $^{13}$ and the human responses to this condition often identified in these patients, ${ }^{6-7}$ construct the conceptual definitions of the elements of the Excessive Liquid Volume (00026) present in the NANDA-I classification (2015-2017). 
These definitions aim to identify such elements of ND in patients with CKD.

\section{OBJECTIVE}

- To construct the conceptual definitions of the components of the Nursing Diagnosis "Excess Fluid Volume (00026)".

\section{METHOD}

It is a bibliographic study, integrative review type developed in six stages: ${ }^{14}$ a) identification of the guiding question; b) sampling or literature search; c) categorization of studies and data collection; d) evaluation of studies included in the integrative review; e) interpretation of results and f) synthesis of evidenced knowledge or presentation of integrative review.

The following guiding question was formulated to guide this review: "How are the elements that make up the ND Excessive Liquid Volume (00026) conceptualized?". The time frame established was from 2012 to 2016. It is reported that this time frame was satisfactory to support the identification of signs and symptoms present in the diagnostic concept and in the construction of definitions.

For the search strategy, a) the controlled descriptors - Health Sciences Descriptors (DeCS) and Medical Subject Headings Terms (MeSH): Anxiety; Azotemia; Dyspnea; Edema; Hepatomegaly; Oliguria; Psychomotor agitation (Restlessness); Pleural effusion; Water imbalance (Electrolyte imbalance); Paroxysmal dyspnea (Paroxysmal nocturnal dyspnea); Pulmonary congestion (pulmonary edema); Systolic Murmus (B3) (Presence of S3heart sound); b) non controlled: Adventitious breath sounds; Alteration in blood pressure; Alteration in mental status; Alteration in pulmonary artery pressure (PAP); Alteration in respiratory pattern; Alteration in urine specific gravity; Anasarca; Decrease in hematocrit; Decrease in hemoglobin; Increase in central venous pressure (PVC); Intake exceeds output; Jugular vein distension; Orthopnea; Positive hepatojugular reflex; Weight gain over short period of time; Compromised regulatory mechanism; Excessive fluid intake and Excessive sodium intake. All descriptors were crossed with the terms Nursing Diagnosis and Renal Insufficiency using the Boolean operator "and".

The following databases were used to capture the studies: MEDLINE (Medical Literature Analysis and Retrieval System Online) via PUBMED (Biomedical Literature Ciattions and Abstracts), CINAHL (Cumulattive Index to Nursing and Allied Health Literature) and Web Of Science. These bases were selected because of their relevance to the areas of health and nursing.
The study inclusion criteria were: studies published from 2012 to 2016, in the area of Nursing, medical and general health, published in English, Portuguese or Spanish. This integrative review excluded editorials, letters, comments, previous notes, abstracts published in events, theses and dissertations. This time band was chosen to ensure the timeliness of the data, given that a larger time frame brought a large number of articles; In addition, the articles not available in full in these databases were found through the collection of the Portal of Periodicals of the Higher Education Personnel Improvement Coordination (CAPES), by academic google or by request to the main author of the research. Articles found were downloaded to Endnote @, and this program found 521 duplicates. The search was performed in non-indexed databases, such as reference books for Semiology and Semiotics, medical area, manuals of care protocols of the Ministry of Health and Guidelines of the Brazilian Society of Nephrology (SBN) and the Brazilian Society of Cardiology (SBC), in addition to the guideline of the International Society of Nephrology for the construction of the definition of some elements that were not covered in the selected articles. The database search took place in January and February 2017.

The selected studies were read in detail and, in order to characterize them, a validated instrument in Brazil was used for data extraction.15 Data was organized in a Microsoft Excel spreadsheet covering the year of publication, title, author (s), journal, country of study origin, study design and objectives, database and level of evidence (LE). ${ }^{15}$

The articles were classified into seven levels regarding evidence: level I - evidence from systematic review or meta-analysis of randomized controlled trials or clinical guidelines based on systematic reviews of randomized controlled trials; level II - evidence derived from at least one well-designed randomized controlled trial; level III - evidence from well-designed clinical trials without randomization; level IV - evidence from well-designed cohort and case-control studies; level V - evidence from systematic review of descriptive and qualitative studies; level VI evidence derived from a single descriptive or qualitative study; level VII - evidence from the opinion of authorities and / or expert committee report. ${ }^{16}$

A total of 2,477 articles were found. After reading the title and abstract, 52 articles in the Web of Science, 30 articles in CINAHL and 41 in PubMed were selected for full reading. Subsequently, the duplicate articles found by Endnote@ in the databases $(n=52)$ and those lacking elements to support the construction of definitions of the proposed terms $(n=50)$ were 
excluded. After full reading, 21 articles were elected because they contain relevant content for the construction of the definitions of the elements of the NANDA-I Excessive Liquid Volume (00026).

Also, due to the difficulty of constructing definitions based on the articles found in the databases, a search in the gray literature was performed. Thus, the final sample consisted of the articles selected in the integrative review, eight textbooks, ${ }^{5,9,17-22}$ a Ministry of Health care protocol manual, ${ }^{23}$ an SBN guideline, ${ }^{24}$ an SBC guideline ${ }^{25}$ and a guideline from the International Society of Nephrology, ${ }^{26}$ totaling 33 items that supported the construction of the definitions of the elements of the NANDA-I Excessive Liquid Volume (00026).

The flow chart shows the Preferred Reporting Items for Systematic Reviews and Meta-Analyzes (PRISMA), ${ }^{27}$ the identification, selection, eligibility and inclusion steps of the studies, as described in figure 1.

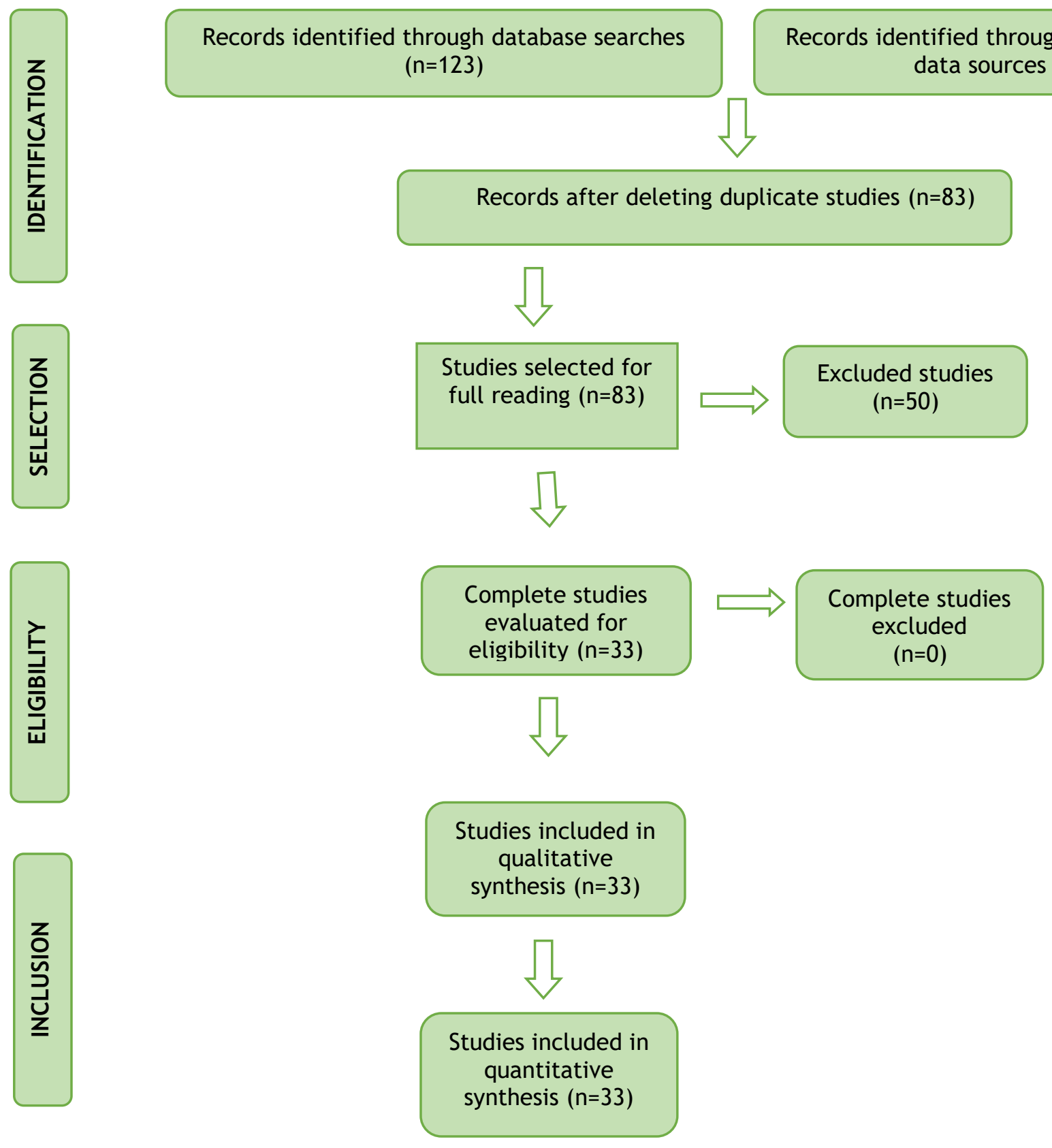

Figure 1. Search and article selection flowchart adapted from Preferred Reporting Items for Systematic Reviews and Meta-Analyzes. (PRISMA). ${ }^{27}$

The content of the articles was maintained without modification in the excerpts extracted for the benefit of the integrative review in order to ensure research ethics.

\section{RESULTS}

Thirty-three studies were found, that supported the construction of the definitions of the terms of DE under study. Of the selected articles, the following journals stood out: International Journal of Nursing Practice; PLOS ONE; Nephrology; The American Journal Nursing; Kidney International; Critical Care; Nursing Standard; Journal of Renal Nutrition; International Journal of Nursing Studies; Medsurg Nursing; Latin American Journal of
Nursing; European Journal of Clinical Nutrition; Intensive Care Medicine; Brazilian Journal of Nursing; Clinical Medicine (Barcelona); Journal of Korean Medical Science; Medicine; Acta Paulista Nursing; Electronic Journal of Nursing and Journal of Nursing of UFSM.

Nine studies were conducted in Europe (England, Spain, Germany, Italy, Portugal and France); ${ }^{28-35,41}$ six in South America (Brazil); $36-40,42$ three in North America (US); ${ }^{43-5}$ one in Oceania (Australia); ${ }^{46}$ one in Asia (Korea) ${ }^{47}$ and a multicenter study involved countries from several continents (Asia, Europe and America); ${ }^{48}$ In terms of language, 14 studies were in English; ${ }^{28-32,34-5,40,43-}$ ${ }^{8}$ six in Portuguese ${ }^{36-9,41-2}$ and one in spanish. ${ }^{33}$ 
The studies consisted of five cohorts; ${ }^{31-2,35,47-8}$ four methodological studies; ${ }^{38-9,42-3}$ two literature reviews; ${ }^{30,44}$ two clinical trials ${ }^{33,40}$ and a qualitative study; ${ }^{46}$ Regarding the approach, five studies used the cross-sectional approach; ${ }^{-29,34,36-7,45}$ one, the retrospective approach ${ }^{28}$ and one study is descriptive-correlational with cluster analysis; ${ }^{41}$ out of 12 studies ${ }^{28-29,31-35,41,45-48}$ developed with adults, four occurred in hemodialysis environment with chronic renal patients ${ }^{28,33-34,41}$ and five studies were developed with children. ${ }^{36-40}$

The articles included in this review are characterized in Figure 2 according to title, country, objectives, level of evidence ${ }^{16}$ and year of publication.

\begin{tabular}{|llr|}
\hline \multicolumn{1}{|c}{ Author } & \multicolumn{2}{c|}{ Title } \\
\hline Andrade, Chaves, Silva, & Respiratory r r & Nursing \\
Beltrão, Lopes. ${ }^{36}$ & Diagnoses for & Children with \\
& Acute r r & Respiratory \\
& Infection. ${ }^{36}$ &
\end{tabular}

Martins, Meireles, Conceptual and operational Rabelo, Aliti. ${ }^{42}$ definitions of the defining characteristics of Nursing Diagnosis Decreased Cardiac Debit. ${ }^{42}$

Yan, Zhu, Li, Shrubsole, Association of High Blood Shi, Zhang, et al. ${ }^{45}$ Pressure with Renal Insufficiency: Role of Albuminuria, from NHANES, 1999-2006. ${ }^{45}$

Perales-Montilla, The influence of emotional Duschek, Paso. ${ }^{33}$ factors on the report of somatic symptoms in patients on chronic haemodialysis: the importance of anxiety. ${ }^{33}$

$\begin{array}{rrlr}\text { Baker, } & \text { Barsamian, } & \text { Routine } & \text { Dyspnea } \\ \text { Leone, } & \text { Donovan, Assessment on Unit }\end{array}$

Williams, Carnevale, et Admission. ${ }^{43}$

al. ${ }^{43}$

Usvyat, Barth, Bayh, Interdialytic weight gain, Etter, von Gersdorff, systolic blood pressure, Grassmann, et al. ${ }^{48}$ serum albumin, and $C$ reactive protein levels change in chronic dialysis patients prior to death. ${ }^{48}$

Teixeira C, Garzotto, Fluid balance and urine Piccinni, Brienza, volume are independent lannuzzi, $\quad$ predictors of mortality in Gramaticopolo, et al. ${ }^{35}$ acute kidney injury. ${ }^{35}$

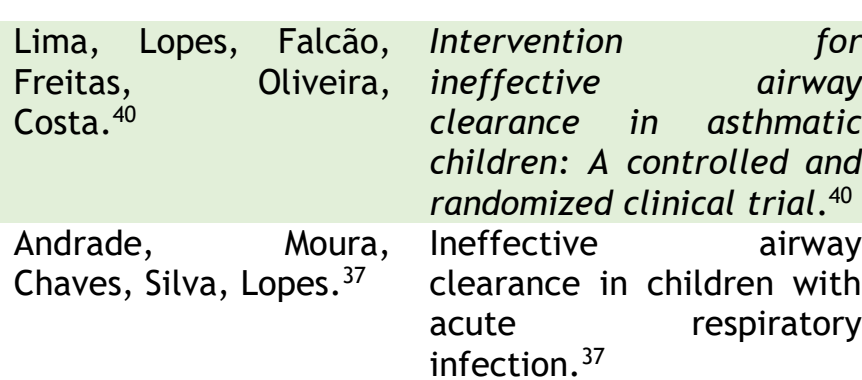

Myatt. ${ }^{30}$

Diagnosis and management of patients with pleural effusions. ${ }^{30}$

Nerbass, Pecoits-Filho, Demographic Associations Mcintyre, Mcintyre, of High Estimated Sodium Willingham, Taal. ${ }^{31}$ Intake and Frequency of Consumption of HighSodium Foods in People With Chronic Kidney

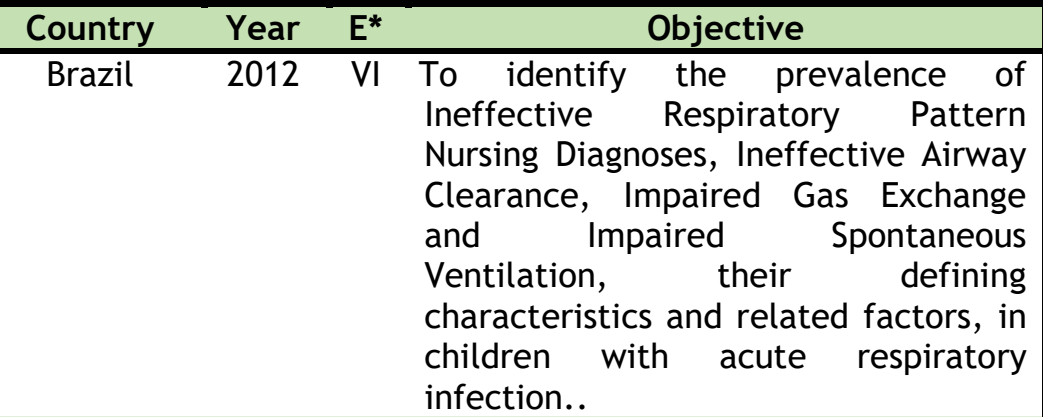

Brazil 2012 VI To elaborate the conceptual and operational definitions of the 38 defining characteristics of the Nursing Diagnosis Decreased Heart Rate.

USA $2012 \mathrm{VI}$ Test the association between hypertension and changes in renal function, considering the level of albuminuria.

Spain 2013 IV To evaluate the presence of different somatic symptoms in hemodialysis patients compared to a control group and to analyze the predictive capacity of some psychological variables such as anxiety, depression, social support, self-efficacy and stress-fighting strategies.

USA $2013 \mathrm{VI}$ To test the feasibility of measuring dyspnea as part of the initial patient assessment by nurses at various inpatient units of a large urban hospital..

Asia, 2013 IV To analyze dynamic changes in weight

Europe, Argentina USA

Italy

2013 IV To evaluate the impact of fluid balance and urine volume on outcomes and determine whether they behave as independent predictors of mortality in adult

patients with acute renal failure.
Brazil 2013 II To analyze the effectiveness of an Intervention for Nursing Diagnosis of Ineffective Airway Clearance in Asthmatic Children.

Brazil 2014 VI To analyze the accuracy of defining characteristics of diagnoses of Ineffective Airway Clearance in children with acute respiratory infection.

England 2014 V Discuss the causes and treatment of pleural effusion, referring to the guidelines produced by the British Thoracic Society.

England 2014 IV To investigate sodium intake in a sample of people with Phase 3 Chronic Kidney Disease to identify demographic characteristics of subgroups with high sodium intake and specific foods that contribute to 


\begin{tabular}{|c|c|c|c|c|c|}
\hline & $\begin{array}{l}\text { Disease Stage } 3 \text { in } \\
\text { England. }{ }^{31}\end{array}$ & & & & excessive sodium intake. \\
\hline $\begin{array}{l}\text { Hosie, Agar, Lobb, } \\
\text { Davidson, Phillips. }{ }^{46}\end{array}$ & $\begin{array}{l}\text { Palliative care nurses' } \\
\text { recognition and assessment } \\
\text { of patients with delirium } \\
\text { symptoms: A qualitative } \\
\text { study using critical } \\
\text { incident technique. }{ }^{46}\end{array}$ & Australia & 2014 & VI & $\begin{array}{l}\text { Explore the experiences, views and } \\
\text { practices of hospice nurses in the } \\
\text { recognition and assessment of } \\
\text { delirium. }\end{array}$ \\
\hline Simon. ${ }^{44}$ & $\begin{array}{l}\text { Leg Edema Assessment and } \\
\text { Management. }{ }^{44}\end{array}$ & USA & 2014 & V & $\begin{array}{l}\text { Discuss different types of edema in } \\
\text { order to enable nurses to } \\
\text { independently and collaboratively } \\
\text { manage lower limb edema in their } \\
\text { patients. }\end{array}$ \\
\hline Gomes, Nóbrega. ${ }^{38}$ & $\begin{array}{l}\text { Anxiety in children } \\
\text { following hospitalization: a } \\
\text { proposal for a nursing } \\
\text { diagnosis. }^{38}\end{array}$ & Brazil & 2015 & $\mathrm{VI}$ & $\begin{array}{l}\text { Describe the process of developing a } \\
\text { Nursing Diagnosis in relation to child } \\
\text { anxiety after hospitalization. } \\
\text { Subsequent to the production of this } \\
\text { process, it would be submitted to the } \\
\text { international classification for nursing } \\
\text { practice, according to the guidelines } \\
\text { established by the International } \\
\text { Council of Nurses and the ISO 18104: } \\
2014 \text { standard. }\end{array}$ \\
\hline $\begin{array}{l}\text { Nerbass, Pecoits-Filho, } \\
\text { Mcintyre, } \\
\text { Taai. }{ }^{32}\end{array}$ & $\begin{array}{l}\text { High sodium intake is } \\
\text { associated with important } \\
\text { risk factors in a large } \\
\text { cohort of chronic kidney } \\
\text { disease patients. }{ }^{32}\end{array}$ & England & 2015 & IV & $\begin{array}{l}\text { To investigate the relationship } \\
\text { between sodium intake and risk } \\
\text { factors for progression of } \\
\text { cardiovascular disease or CKD in a } \\
\text { sample of phase } 3 \text { CKD patients } \\
\text { recruited from primary care. }\end{array}$ \\
\hline $\begin{array}{l}\text { Legrand, Jacquemod, } \\
\text { Gayat, } \quad \text { Collet, } \\
\text { Giraudeaux, Launay, et } \\
\text { al. }{ }^{29}\end{array}$ & $\begin{array}{l}\text { Failure of renal biomarkers } \\
\text { to predict worsening renal } \\
\text { function in high-risk } \\
\text { patients presenting with } \\
\text { oliguria. }{ }^{29}\end{array}$ & France & 2015 & VI & $\begin{array}{l}\text { To explore the predictive value of } \\
\text { biomarkers for predicting renal } \\
\text { function in intensive care unit oliguric } \\
\text { patients. }\end{array}$ \\
\hline Cristóvão. ${ }^{41}$ & $\begin{array}{l}\text { Fluid and dietary } \\
\text { restriction's efficacy on } \\
\text { chronic kidney disease } \\
\text { patients in hemodialysis. }{ }^{41}\end{array}$ & Portugal & 2015 & IV & $\begin{array}{l}\text { Identify the self-care measures used in } \\
\text { wa. }\end{array}$ \\
\hline $\begin{array}{l}\text { Gomes, } \\
\text { Nobrega. }{ }^{39}\end{array}$ & $\begin{array}{ll}\text { Hospitalization } & \text { anxiety in } \\
\text { children: } & \text { conceptual } \\
\text { analysis. } & \end{array}$ & Brazil & 2016 & $\mathrm{VI}$ & $\begin{array}{l}\text { To analyze the concept of } \\
\text { hospitalization anxiety in children, } \\
\text { identifying their antecedents, } \\
\text { attributes and consequences, in order } \\
\text { to clarify its meaning. }\end{array}$ \\
\hline $\begin{array}{l}\text { Reque, Quiroga, Ruiz, } \\
\text { Villaverde, Veja, Abad, } \\
\text { et al. }{ }^{34}\end{array}$ & $\begin{array}{l}\text { Pulmonary hypertension in } \\
\text { hemodialysis patients: } \\
\text { Prevalence and associated } \\
\text { factors. }^{34}\end{array}$ & Spain & 2016 & $\mathrm{VI}$ & $\begin{array}{l}\text { To establish the prevalence of } \\
\text { pulmonary hypertension in patients } \\
\text { undergoing hemodialysis and its } \\
\text { association with specific factors } \\
\text { related to this patient population. }\end{array}$ \\
\hline Kim, Kim, Kwon, Kim. ${ }^{47}$ & $\begin{array}{l}\text { Erythropoiesis-stimulating } \\
\text { Agents and Anemia in } \\
\text { Patients with Non-dialytic } \\
\text { Chronic Kidney Disease. }{ }^{47}\end{array}$ & $\begin{array}{l}\text { South } \\
\text { Korea }\end{array}$ & 2016 & IV & $\begin{array}{l}\text { To investigate the impact of } \\
\text { reimbursement of erythropoiesis } \\
\text { stimulating agents on the treatment } \\
\text { of anemia in patients with non- } \\
\text { dialytic CKD. }\end{array}$ \\
\hline $\begin{array}{l}\text { Becker, Walter, Witzke, } \\
\text { Korber, } \quad \text { Bienholz, } \\
\text { Kottmann, et al. }{ }^{28}\end{array}$ & $\begin{array}{l}\text { Edema, } \\
\text { Hyperpigmentation, } \\
\text { Induration: } 3 \text { Skin Signs } \\
\text { Heralding Danger in } \\
\text { Patients on Maintenance } \\
\text { Hemodialysis. }{ }^{28}\end{array}$ & Germany & 2016 & $\mathrm{VI}$ & $\begin{array}{l}\text { Focus on the putative putative } \\
\text { associations of skin-specific findings } \\
\text { with comorbidity and mortality. }\end{array}$ \\
\hline
\end{tabular}

Figure 2. Description of studies in relation to title, objectives, country and level of evidence published from 2012 to 2016. Campinas, SP, Brazil, 2017. * Level of evidence.

At the time of the research proposal, as well as at the beginning of the data collection, the RF and $D C$ of the $D C$ under study were considered as elements to be evaluated, according to the NANDA-I version (2015-2017). ${ }^{4}$ During the study period, we opted for the publication of the new version of NANDA-I (2018-2020), ${ }^{5}$ for readjusting the nomenclature of the elements that make up the ND; Thus, the element "Committed Regulatory Mechanism", considered as RF until then, has been renamed $C A$, and the conceptual definitions of the elements of ND Excessive Liquid Volume (00026) are presented in Figure 3. 
Related factors

Excessive fluid intake

intake

Associated Condition

Regulatory mechanism

compromised

\section{Defining}

characteristics

Alteração

gravidade

da urina

Pulmonary Arterial

Pressure Change (PAP)

Change in blood

pressure

Alteration in mental

state

Change in breathing

pattern

Anasarca

Anxiety

Azotemia

Pulmonary congestion

Pleural effusion

Electrolyte imbalance

Dyspnea

Paroxysmal nocturnal dyspnea

Jugular Vein

Distension

Edema

Weight Gain in a Short Time

Decreased hematocrit

Decreased hemoglobin

Hepatomegaly

Ingestion greater than elimination

Restlessness

Oliguria

Orthopnea
Conceptual Definitions

Difficulty in managing thirst and, consequently, fluid intake above recommended, leading to increased interdialytic weight gain. ${ }^{41}$

Sodium consumption above $2 \mathrm{~g} /$ day, corresponding between $5 \mathrm{~g}$ and $6 \mathrm{~g}$ sodium chloride. 20,23,26,31-32

\section{Conceptual Definitions}

Impairment of the body fluid regulation mechanism that is maintained by a precise interaction between the intake and output of the kidneys, loss through the skin and lungs, and function of hydrostatic pressure within the cell compartment and osmolarity within each compartment. ${ }^{49}$ Conceptual Definitions

na Change in the measurement of the density of dissolved chemicals in the urine and influenced by both the number of particles present and the size of the particles that may indicate dehydration and excess substances in the urine, reflecting excess substances in the blood. The change in reference values is an indication of renal dysfunction. Normal values / hydration: 1010-1025; concentrated urine: greater than or equal to 1025; diluted urine: 1001-1010. ${ }^{17}$

Multifactorial clinical condition characterized by elevated or decreased blood pressure levels. ${ }^{25,45}$

Attitudes manifesting altered mental functions involving altered consciousness, attention, sense-perception, orientation, memory, intelligence, affectivity and mood, thinking, critical judgment, conduct and language. ${ }^{46}$

Respiratory rate below or above the proposed values for the patient's age range. Respiratory rate between 16 to 20 irpm in adults is considered ideal (eupnea). ${ }^{50}$

General accumulation of fluid in the interstitial space. ${ }^{21}$

Vague and uncomfortable feeling of discomfort or fear accompanied by autonomic response (source is often non-specific or unknown to the individual). It is a warning sign that draws attention to an imminent danger and allows the individual to take action to deal with the threat. ${ }^{5,33,38-9}$

Biochemical abnormality that refers to an elevation in plasma urea and creatinine levels and is largely due to a decreased Glomerular Filtration Rate (GFR. ${ }^{19}$

Liquid accumulation in the interstitial and alveolar space, preventing adequate diffusion of oxygen and carbon dioxide. ${ }^{18}$

Accumulation of fluid between the visceral and parietal pleura that spills into the chest cavity, preventing the lung from fully expanding during inspiration. ${ }^{30}$

Changes in electrolyte levels: hypernatremia: sodium level greater than $145 \mathrm{mEq} / \mathrm{L}$; hyperkalemia: potassium level greater than $5.5 \mathrm{mEq} / \mathrm{L}$; hypercalcemia: calcium level greater than $10.4 \mathrm{mg} / \mathrm{dL}$; hyperchloremia: chloride level above $103 \mathrm{mEq} / \mathrm{L}$; hyperphosphatemia: phosphorus level greater than $4.6 \mathrm{mg} / \mathrm{dL}$; hypermagnesemia: magnesium level greater than $2.6 \mathrm{mg} / \mathrm{dL} .{ }^{17,26}$

Subjective experience of respiratory discomfort that consists of qualitatively distinct sensations, which may vary in intensity, from the reference to "tiredness" to "breathlessness". It usually occurs secondary to reduced cardiac and pulmonary perfusion and consequently to reduced cardiac contractility, either by decreased erythropoietin production or pulmonary congestion due to increased fluid in the alveolar space. ${ }^{43,51}$

Difficulty breathing at night after the patient has slept for a few hours, caused by increased venous return. ${ }^{50}$ Sleep is interrupted due to respiratory distress, causing the patient to sit on the bed or get up with choking sensation, dry cough and chest tightness. ${ }^{52}$

State in which jugular vein turgence is observed when the patient is in the sitting / lying position at $45^{\circ}$. Sign indicating systemic congestion. ${ }^{21}$

Excess fluid accumulated in the interstitial space (skin and subcutaneous cellular screen) 20 or within the cells themselves; as a consequence there are changes in sodium and water homeostasis. ${ }^{22,28,44}$

Interdialytic weight gain (IWG), which is used to assess how the patient controls his fluid and nutritional intake, is calculated in kilograms or as a percentage of the individual's dry weight. 41 On average, weight gain should be less than or equal to to $4.5 \%$ of the individual's dry weight. ${ }^{48,53}$

Hematocrit level less than $36 \%$ in women and less than $42 \%$ in men. ${ }^{17}$

Hemoglobin level less than $13 \mathrm{~g} / \mathrm{dL}$ in men and hemoglobin level less than $12 \mathrm{~g} / \mathrm{dL}$ in women or men over 65 years. ${ }^{24,26,47}$

Increased liver volume. ${ }^{54}$

Imbalance between sodium and water excretion and, consequently, there is fluid ingress and loss by breathing, perspiration, urine and feces, which leads to fluid accumulation. 9,35

Alteration of behavior with irritability, moodiness, psychomotor instability and restlessness, being observed by the examiner and validated by information from family members and the patient. $^{42}$

Diuresis less than $400 \mathrm{ml} / 24 \mathrm{~h}$ or less than $20 \mathrm{ml} / \mathrm{h}^{29,51}$

Breathing difficulty that appears or worsens with the adoption of the horizontal position; As a result, there is decreased pulmonary expansion and malfunction in this position due to fluid 
Presence of the third

heart sound (B3)

Increased Central

Venous Pressure (PVC)

Positive hepatojugular

reflex

Noises

accumulation, tending to partially or fully relieve the upper chest. ${ }^{21,37,40,42}$

Cardiac auscultation of an "additional" noise that occurs at the onset of diastole and arises from the vibrations of the ventricular wall suddenly distended by the blood flow entering the cavity during rapid ventricular filling. It is more audible with the patient lying in the left lateral position. ${ }^{51}$

Increased right atrial pressure measurement which refers to the right ventricular filling capacity (preload) at the end of diastole and represents the measure of the heart's ability to pump blood. Reference value from eight to $12 \mathrm{~cm} \mathrm{H} 20.42$

Sign of jugular vein filling when compression is applied over the hepatic topography located in the right hypochondrium. ${ }^{21}$

Abnormal sounds (rales, snores, wheezing, crackling and / or pleural friction) produced by the passage of air in the occluded respiratory tract and / or air collision with tracheobronchial secretions. ${ }^{36-7}$

Figure 3. Conceptual definitions of elements of Nursing Diagnosis. Excess Fluid Volume (00026). Campinas, SP, Brazil, 2017.

\section{DISCUSSION}

NANDA-I, through SLS, names the phenomena that individuals present and are sensitive to nursing actions. It is clear that these systems guide the work of nurses, however, it is relevant to emphasize that their clinical judgment must be accurate so that care planning meets the specific clinical situations of the patients treated. ${ }^{55}$ It is trusted as a strategy to approach nurses with validation studies that provide for the evaluation of the elements that make up NDs, either by judges in the validation of a given content and / or by nurses in a clinical environment in which care is exercised. with a certain population.

It is proposed, among the various existing methodologies, by Content Analysis, to perform the integrative review in order that the phenomenon of interest is explored and known in depth. ${ }^{12}$ The integrative review supported the construction of definitions that will assist in the recognition of the element (conceptual definition) as well as its measurement (operational definition). These definitions contribute to the knowledge of the elements that make up the phenomenon studied through its clear and objective description.

In this study, we sought to construct the conceptual definitions of RF and DC of Excessive Liquid Volume (00026), since the work developed by a group of scholars from the Federal University of São Paulo (UNIFESP) ${ }^{56}$ brings the operational definitions of this diagnostic concept. The importance of describing such phenomena is understood so that the nurse is assisted in the proposition of ND that represents, in fact, the answer presented by the patient, since it clarifies the terms with standardized definitions. In addition, knowledge about conceptual and operational definitions can support the teaching of the Nursing discipline and future research with a studied phenomenon, which may contribute to avoid misunderstandings in the assessment of patients..
The studies that determine the presence of the referred ND and its elements are guided by the proposition of the concept with greater accuracy by the nurse. For some, the prevalence of these indicators for patients with excessive fluid volume is shown (00026)..$^{6,757,58}$ In one study, the most frequent NDs in chronic renal patients undergoing hemodialysis were identified and this diagnostic concept was present in $100 \%$ of the 28 selected patients. ${ }^{6}$ In addition to the prevalence of ND, it is relevant to understand which clinical indicators have been validated in specific populations. This knowledge can help in understanding how the human response develops, its determinants and consequences, and also in favoring the planning of nursing care.

It is important for the nurse to recognize the complications that CKD patients may have, and among them, acute pulmonary edema, fluid overload and, consequently, circulatory, which may lead to decreased cardiac pump efficiency, resulting in congestive heart failure and systemic arterial hypertension, as well as coronary artery disease and cerebrovascular problems. ${ }^{6,49,59}$ Prevention and control of these complications depend on the correct evaluation by the nurse. Therefore, it is essential that it seeks to identify, among the patients under its care, those who are affected by such complications so that nursing care meets the urgent need of each individual.

In another study, ${ }^{60}$ the prevalence of RF and $C D$ in patients undergoing hemodialysis was verified, also identifying the association of these elements with sociodemographic and clinical variables. The $C D$ presented azotemia, decreased hematocrit, electrolyte imbalance, ingestion greater than elimination, anxiety and edema, prevalence over $80 \%$ in the study sample, being considered relevant indicators for diagnostic inference; The compromised regulatory mechanism and excessive sodium intake elements were $100 \%$ prevalent, being considered relevant indicators for the development of this diagnosis.

In a study carried out in a university hospital in northeastern Brazil, with 100 patients undergoing hemodialysis, the accuracy of the DC of the 
phenomenon under study regarding sensitivity, specificity and positive and negative predictive values was evaluated. It was concluded that the most sensitive indicator was edema and the most specific indicators were pulmonary congestion, adventitious respiratory noise and agitation. ${ }^{58}$

In a research conducted with 98 hospitalized adult patients undergoing hemodialysis, the presence of the DCs from the nursing consultation and physical examination, as well as from the evaluation of laboratory tests, was investigated. The determinant indicators in this analysis are known to be decreased hemoglobin and hematocrit, present in $97 \%$ of the sample, followed by electrolyte imbalance, in $62 \%$; oliguria in $67 \%$ of patients; adventitious breathing noises, in 59\%; edema and ingestion greater than elimination, in $52 \%$, respectively. ${ }^{7}$

It is guided by the clinical evidence produced by studies in the area, in fact, the practice of care, which gives legitimacy to the actions. It is understood that the accuracy in identifying the signs and symptoms that contribute to the occurrence of the phenomena is indisputable for a diagnostic reasoning with higher predictive value. It is necessary to approach the nurse with the studies that name, define and validate the components of NDs to improve the quality of care and directly influence the reestablishment of health conditions of patients treated.

One can, by constructing the conceptual definitions of the elements that make up the diagnostic concept, through the integrative review, better describe what is in practice; In addition, it can favor the planning of nursing care offered, minimizing the complications and suffering of patients.

It is pointed out that, of the indicators evidenced in the reported studies, the defining characteristic agitation is translated by the restlessness indicator. This behavior change can be observed, in which the patient presents irritability, moodiness and psychomotor instability, by the examiner, validating it by information from family members and the patient. ${ }^{42}$ This indicator is due to the alteration of electrolytes and the excess volume of fluid in the lungs, respiratory distress and, consequently, decreased oxygen supply to brain tissues. ${ }^{49,5}$ In this context, it is also prevented by the pulmonary congestion element, translated by the accumulation of fluid in the interstitial and alveolar space, the adequate diffusion of oxygen and carbon dioxide, ${ }^{18}$ further compromising the breathing pattern. Associated with this is the deficiency in erythropoietin production due to inactivity of the adrenal gland, responsible for the constant respiratory fatigue in these patients and for the anemia detected based on low hemoglobin and hematocrit levels in laboratory tests. ${ }^{19}$

In association with this condition, adventitious breathing noises arise. These are abnormal sounds originating from the collision of air with tracheobronchial secretions; in this case, due to excess pulmonary fluid present in the respiratory tract. $^{37}$ These DC are known to be justified by another indicator present in this population, edema, considered in some studies as sensitive to the occurrence of excess fluid; ${ }^{58,60}$ This is the most common cause of hospitalization of these patients, in addition to being directly associated with the indicators higher ingestion than debt, short-term weight gain and jugular distension caused by systemic congestion established in CKD. ${ }^{21}$ This systemic congestion can interfere with the return of blood to the heart and cause numerous problems, such as respiratory distress, tachypnea, increased heart rate, fatigue and change in level of consciousness.

Electrolyte alteration was found as another indicator evidenced in a study, ${ }^{60}$ since renal failure prevents the regulation of important elements for the maintenance of the body's homeostasis. Thus, serum accumulation is favored, causing hypernatremia, hyperkalemia, hypocalcemia, hyperchloremia, hyperphosphatemia, hypermagnesemia, among others, leading to various systemic complications.

This whole picture, which characterizes the human response under study and may cause severe complications to the patient with CKD, needs to be thoroughly studied. Therefore, the proposition of this study, which is relevant for the execution of the next phases, such as content and clinical validation, is justified.

It is believed that the construction of conceptual definitions is a strategy in the search for standardization of the language used by nurses, which aims to facilitate communication between team members, improve diagnostic accuracy and care planning, and contribute to research in the area, favoring the teaching of the Nursing discipline. It is emphasized the relevance of deepening the knowledge about the phenomena presented by the patients, and the description of elements that compose such phenomena helps in this deepening and, consequently, legitimizes nursing care.

\section{CONCLUSION}

It is inferred, after analyzing the articles included in this review, that the main indicators related to excess liquids supported the construction of the definitions of RF, CA and DC presented by NANDA-I. The clinical evidence found in the studies was generally related to hypertension, edema, water and dietary intake, 
respiratory changes, biochemical changes, changes in mental status, weight gain and urinary elimination.

Based on the definitions constructed in this study, the recognition of each of the indicators that make up the diagnostic concept Excessive Liquid Volume (00026) is directed, as well as helping nurses to plan their actions in accordance with the patients' needs. Nevertheless, nursing knowledge is favored and the development of the language used by nurses is encouraged, because, despite the advancement of existing treatments, patients constantly have complications arising from CKD. Fluid retention is the main complication present in these patients, as a human response of interest and responsibility of the Nursing team.

Regarding the phenomenon under study, the construction of definitions facilitates the understanding of ND by the interdisciplinary team, enabling more efficient and uniform patient care. Understanding of this phenomenon becomes easier and such definitions can be used as a teaching strategy, as well as facilitating Nursing registration and data analysis of patients with excess fluid volume.

As a limiting factor of the study, we highlight the need for increment through the gray literature, considering that not all elements could be included in the studies included in this review. It is considered that this study will contribute to the next steps of the validation process of this diagnosis in the CKD population, content analysis and clinical validation that are already being conducted.

\section{FUNDING}

Higher Education Personnel Improvement Coordination (CAPES) for granting a PhD scholarship.

\section{REFERENCES}

1. Lei 7.498, de 25 de junho de 1986 (BR). Dispõe sobre a Regulamentação do Exercício da Enfermagem e dá outras providências. Diário Oficial da União [Internet]. 1986 June 25 [cited 2019 Aug 10]. Available from: http://www.planalto.gov.br/ccivil_03/leis/L7498. $\underline{\mathrm{htm}}$

2. Conselho Federal de Enfermagem. Resolução COFEN no 358 de 15 de outubro de 2009. Dispõe sobre a Sistematização da Assistência de Enfermagem e a implementação do Processo de Enfermagem em ambientes, públicos ou privados, em que ocorre o cuidado profissional de Enfermagem, e dá outras providências [Internet]. Brasília: COFEN; 2009 [cited 2019 Apr 15]. Available from: http://www.cofen.gov.br/resoluocofen-3582009_4384.html
3. Silva ERR, Azzolin KO, Lucena AF, Lima LB, Lemos DMP, Cavalcanti ACD, Almeida MA. Relevância da aplicação NANDA-I, NIC e NOC na prática clínica. In: NANDA International. PRONANDA Programa de atualização em Diagnóstico de Enfermagem: ciclo 3, volume 3. Porto Alegre: Artmed; 2015. p. 59-90.

4. Herdman TH, Kamitsuru S. editors. NANDA International nursing diagnoses: definitions and classification, 2015-2017. 10th ed. Oxford: WileyBlackwell; 2015.

5. Herdman TH, Kamitsuru S. editors. NANDA International nursing diagnoses: definitions and classification, 2018-2020. 11th ed. Oxford: Thieme; 2018.

6. Debone MC, Pedruncci ESN, Candido MCP, Marques S, Kusumota L. Nursing diagnosis in older adults with chronic kidney disease on hemodialysis. Rev Bras Enferm. 2017 July/Aug;70(4):800-5. DOI: 10.1590/0034-71672017-0117

7. Grassi MF, Dell'Acqua MCQ, Jensen R, Fontes CMB, Guimarães HCQCP. Diagnosis, results, and nursing interventions for patients with acute renal injury. Acta Paul Enferm. 2017 Sept/Oct;30(5):53845. DOI: $10.1590 / 1982-0194201700078$

8. Sousa LMM, Marques-Vieira CMA, Severino SSP, Rosado JLP, José HMG. Validation of the positive and negative affect schedule in People with chronic kidney disease. Texto contexto-enferm. 2016 Dec;25(4):e5610015. DOI: 10. 1590/010407072016005610015

9. Hinkle JL, Cheever KH, editors. Brunner \& Suddarth: tratado de enfermagem médicocirúrgica. 13th ed. Rio de Janeiro: Guanabara Koogan; 2016.

10. Goncalves MCS, Brandao MAG, Duran ECM. Validation of the defining characteristics of the nursing diagnosis impaired comfort in oncology. Acta Paul Enferm. 2016 Jan/Feb;29(1);115-24. DOI: $\underline{10.1590 / 1982-0194201600016}$

11. Reis GS, Reppetto MA, Santos LSC, Devezas AMLO. Systematization of nursing care: advantages and difficulties in implementation. Arq Med Hosp Fac Cienc Med Santa Casa São Paulo [Internet]. 2016 [cited 2018 Aug 10];61:128-32. Available

from:

http://arquivosmedicos.fcmsantacasasp.edu.br/in dex.php/AMSCSP/article/viewFile/101/101

12. Soares CB, Hoga LAK, Peduzzi M, Sangaleti C, Yonekura T, Silva DRAD. Integrative review: concepts and methods used in nursing. Rev EsC Enferm USP. 2014 June;48(2):329-39.DOI: 10.1590/S0080-6234201400002000020

13. Thomé FS, Sesso RC, Lopes AA, Lugon JR, Martins CT. Brazilian Chronic Dialysis Survey 2017. J Bras Nefrol. 2019 Apr/June; 41(2):208-14. DOI: 10.1590/2175-8239-JBN-2018-0178

14. Whittemore $R$, Knafl K. The integrative review: updated methodology. J Adv Nurs. 2005 
Dec; 52(5):546-53. DOI: 10.1111/j.13652648.2005.03621.x

15. Ursi ES, Galvão CM. Perioperative prevention of skin injury: an integrative literature review. Rev Latino-Am Enfermagem. 2006 Jan/Feb;14(1):124-31. DOI: 10.1590/S010411692006000100017

16. Stillwell SB, Fineout-Overholt E, Melnyk BM, Williamson KM. Evidence-based practice, step by step: searching for the evidence. Am J Nurs. 2010 May;110(5):41-7.

DOI:

10.1097/01.NAJ.0000372071.24134.7e

17. Fischbach FT, Dunning MB. Exames laboratoriais e diagnóstico em enfermagem. 9th ed. Rio de Janeiro: Guanabara Koogan; 2016.

18. Gonçalves CCS. Avaliação do Sistema Respiratório em Terapia Intensiva. In: Cheregatti $\mathrm{AL}$, Amorim $\mathrm{CP}$, organizadoras. Enfermagem em unidade de terapia intensiva. São Paulo: Martinari; 2011. p. 201-72.

19. Kumar V, Abbas AK, Aster JC. Robbins \& Cotran patologia: bases patológicas das doenças. 9th ed. Rio de Janeiro: Elsevier; 2016.

20. Almeida FA, Rodrigues CIS. Hipertensão Arterial Primária. In: Riella MC, editor. Princípios da Nefrologia e Distúrbios Hidroeletrolítico. 4th ed. Rio de Janeiro: Guanabara Koogan; 2010. p.730-56.

21. Pokorski SCS, Aliti GB, Souza PS, Lucena AF, Silva ERR. Diagnóstico de enfermagem com base em sinais e sintomas do sistema cardiovascular. In: Silva EER, Lucena AF, editoras. Diagnóstico de enfermagem com base em sinais e sintomas. Porto Alegre: Artmed; 2011. p.111-32.

22. Branco RFGR, Pinho FMO, Porto AL, Porto CC. Exame físico geral. In: Porto $\mathrm{CC}$, Porto $\mathrm{AL}$, editores. Exame clínico. 8th ed. Rio de Janeiro: Guanabara Koogan; 2017. p.201-45.

23. Ministério da Saúde (BR), Secretaria de Atenção à Saúde, Departamento de Atenção Especializada e Temática, Coordenação Geral de Média e Alta Complexidade. Diretrizes Clínicas para o Cuidado ao paciente com Doença Renal Crônica no Sistema Único de Saúde [Internet]. Brasília: Ministério da Saúde; 2014 [cited 2019 Aug 10]. Available from: http://bvsms.saude.gov.br/bvs/publicacoes/diretr izes_clinicas_cuidado_paciente_renal.pdf

24. Ribeiro-Alves MA, Gordan PA. Diagnosis of anemia in patients with chronic kidney disease. J Bras Nefrol. 2014 Aug/Jan;36(Suppl 1):9-12. DOI: 10.5935/0101-2800.2014S003

25. Sociedade Brasileira de Cardiologia. Hipertensão e condições clínicas associadas. Arq Bras Cardiol [Internet]. 2016 [cited 2019 June 15];17(1):57-60.

DOI:

http://departamentos.cardiol.br/dha/revista/171/13-cap09.pdf

26. International Society of Nephrology. Clinical Practice Guideline for the Evaluation and
Management of Chronic Kidney Disease. Kidney International Supplements [Internet]. 2013 Jan [cited 2018 Aug 10];3(1):1-150. Available from: http://www.kdigo.org/clinical_practice_guideline s/pdf/CKD/KDIGO_2012_CKD_GL.pdf

27. Moher D, Liberati A, Tetzlaff J, Altman DG, Prisma Group. Preferred reporting items for systematic reviews and meta-analyses: the PRISMA Statement. PloS Med. 2009July;6(7):e1000097. DOI: 10.1371/journal.pmed.1000097

28. Becker S, Walter S, Witzke O, Korber A, Bienholz A, Kottmann T, et al. Edema, Hyperpigmentation, Induration: 3 Skin Signs Heralding Danger in Patients on Maintenance Hemodialysis. Medicine (Baltimore). 2016 Mar; 95(12):e3121. DOI: 10.1097/MD.0000000000003121 29. Legrand $M$, Jacquemod A, Gayat E, Collet C, Giraudeaux V, Launay JM, et al. Failure of renal biomarkers to predict worsening renal function in high-risk patients presenting with oliguria. Intensive Care Med. 2015 Jan;41(1):68-76. DOI: 10.1007/s00134-014-3566-3.

30. Myatt R. Diagnosis and management of patients with pleural effusions. Nurs Stand. 2014 Jun;28(41):51-8. DOI: 10.7748/ns.28.41.51.e884

31. Nerbass FB, Pecoits-Filho R, Mcintyre NJ, Mcintyre CW, Willingham FC, Taal MW. Demographic Associations of High Estimated Sodium Intake and Frequency of Consumption of High-Sodium Foods in People With Chronic Kidney Disease Stage 3 in England. J Ren Nutr. 2014 July;24(4):236-42. DOI: 10.1053/j.jrn.2014.03.003 32. Nerbass FB, Pecoits-Filho R, Mcintyre NJ, Mcintyre CW, Taai MW. High sodium intake is associated with important risk factors in a large cohort of chronic kidney disease patients. Eur J Clin Nutr. 2015 July;69(7):786-90. DOI: 10.1038/ejcn.2014.215.

33. Perales-Montilla CM, Duschek S, Paso GAR. The influence of emotional factors on the report of somatic symptoms in patients on chronic haemodialysis: the importance of anxiety. Nefrologia. 2013 Nov;33(6):816-25. DOI: 10.3265/Nefrologia.pre2013. Aug. 12097.

34. Reque J, Quiroga B, Ruiz C, Villaverde MT, Veja A, Abad S, et al. Pulmonary hypertension in hemodialysis patients: Prevalence and associated factors. Med Clin (Barc). 2016 Feb; 146(4):143-7. DOI: $10.1016 /$ j.medcli.2015.06.019.

35. Teixeira C, Garzotto F, Piccinni P, Brienza N, lannuzzi M, Gramaticopolo S, et al. Fluid balance and urine volume are independent predictors of mortality in acute kidney injury. Crit Care. 2013 Jan;17(1);R14. DOI: 10.1186/cc12484.

36. Andrade LZC, Chaves DBR, Silva VM, Beltrão BA, Lopes MVO. Respiratory nursing diagnoses for children with acute respiratory infection. Acta Paul Enferm. 2012;25(5):713-20. DOI: 10.1590/S0103-21002012000500011 
37. Andrade LZC, Moura KKM, Chaves DBR, Silva VM, Lopes MVP. Ineffective airway clearance in children with acute respiratory infection. Rev eletrônica enferm. 2014 Jan/Mar;16(1):21-7. DOI: $\underline{10.5216 / \mathrm{ree} . \mathrm{v} 16 \mathrm{i1} .20315}$

38. Gomes GLL, Nóbrega MML. Anxiety in children following hospitalization: a proposal for a nursing diagnosis. Rev Latino-Am Enfermagem. 2015 Sept/Oct;23(5):963-70. DOI: 10.1590/01041169.0372.2637

39. Gomes GLL, Fernandes MGM, Nobrega MML. Hospitalization anxiety in children: conceptual analysis. Rev Bras Enferm. 2016 Sept/Oct;69(5):884-9. DOI: $10.1590 / 0034-7167-$ 2015-0116

40. Lima LH, Lopes MVO, Falcão RT, Freitas RMR, Oliveira TF, Costa MC. Intervention for ineffective airway clearance in asthmatic children: a controlled and randomized clinical trial. Int J Nurs Pract. $2013 \quad$ Feb;19(1):88-94. DOI: 10.1111/ijn.12033

41. Cristóvão AF. Fluid and dietary restriction's efficacy on chronic kidney disease patients in hemodialysis. Rev Bras Enferm. 2015 Nov/Dec;68(6):1154-62. DOI: 10.1590/00347167.2015680622i.

42. Martins QCS, Meireles PF, Rabelo ER, Aliti GB. Conceptual and operational definitions of defining characteristics of decreased cardiac output nursing diagnosis. Rev Enferm UFSM. 2012 May/Aug;2(2):420-33. DOI: 10.5902/217976923191 43. Baker K, Barsamian J, Leone D, Donovan BC, Williams D, Carnevale K, et al. Routine Dyspnea Assessment on Unit Admission. Am J Nurs. 2013 Nov;113(11):42-9.

DOI:

10.1097/01.NAJ.0000437112.43059.a0.

44. Simon EB. Leg Edema Assessment and Management. Medsurg Nurs [Internet]. 2014 Jan/Feb [cited 2018 Aug 10];23(1):44-53. Available from:

https://www.ncbi.nlm.nih.gov/pubmed/24707668

45. Yan P, Zhu X, Li H, Shrubsole MJ, Shi H, Zhang $M$, et al. Association of High Blood Pressure with Renal Insufficiency: Role of Albuminuria, from NHANES, 1999-2006. PLoS One. 2012;7(7):e37837. DOI: $10.1371 /$ journal.pone.0037837

46. Hosie A, Agar M, Lobb E, Davidson PM, Phillips J. Palliative care nurses' recognition and assessment of patients with delirium symptoms: a qualitative study using critical incident technique. Int J Nurs Stud. 2014 Oct; 51(10):1353-65. DOI: 10.1016/j.ijnurstu.2014.02.005

47. Kim SM, Kim KM, Kwon SK, Kim HY. Erythropoiesis-stimulating Agents and Anemia in Patients with Non-dialytic Chronic Kidney Disease. J Korean Med Sci. 2016 Jan;31(1):55-60. DOI: 10.3346/jkms.2016.31.1.55

48. Usvyat LA, Barth C, Bayh I, Etter M, von Gersdorff GD, Grassmann A, et al. Interdialytic weight gain, systolic blood pressure, serum albumin, and C-reactive protein levels change in chronic dialysis patients prior to death. Kidney Int. 2013 July;84(1):149-57. DOI: 10.1038/ki.2013.73

49. Zatz R. Insuficiência Renal Crônica (IRC). In: Riella MC, editor. Princípios da Nefrologia e Distúrbios Hidroeletrolítico. 4th ed. Rio de Janeiro: Guanabara Koogan; 2010. p.649-60.

50. Porto CC, Porto AL, Moreira MAC, Freitas Jr AF, Neto AA, Moraes AVS, Castro EC. Exame do Tórax. In: Porto CC, Porto AL, editores. Exame clínico. 8th ed. Rio de Janeiro: Guanabara Koogan; 2017. p.319-76.

51. Porto CC, Porto AL. Sinais e Sintomas. In: Porto CC, Porto Al, editores. Exame clínico. 8th ed. Rio de Janeiro: Guanabara Koogan; 2017; p. 57-156.

52. Dezorzi LW, Boaz SK, Echer IC. Diagnóstico de enfermagem com base em sinais e sintomas do sistema respiratório. In: Silva ERR, Lucena AF, editoras. Diagnóstico de enfermagem com base em sinais e sintomas. Porto Alegre: Artmed; 2011; p.93-109.

53. Ferraz SF, Freitas ATVS, Vaz IMF, Campos MIVAM, Peixoto MRG, Pereira ER. Nutritional status and interdialytic weight gain of chronic hemodialysis patients. J Bras Nefrol. 2015 July/Sept;37(3):306-14. DOI: $10.5935 / 0101$ $\underline{2800.20150050}$

54. Porto CC, Silvério AO, Oliveira CP, Rezende JM, Rosa H, Moreira H. Exame do Abdome. In: Porto CC, Porto AL, editores. Exame clínico. 8th ed. Rio de Janeiro: Guanabara Koogan; 2017. p.377-407.

55. Correia MDL, Duran ECM. Conceptual and operational definitions of the components of the nursing diagnosis Acute Pain (00132). Rev LatinoAm Enfermagem. 2017 Dec;25:e2973. DOI: 10.1590/1518-8345.2330.2973

56. Boery RNSO, Guimarães HCQCP, Barros ALBL. Operational definitions of the defining characterístics of the nursing diagnosis Fluid Volume Excess. Acta Paul Enferm. 2005 Apr/June;18(2):197-202. DOI: 10.1590/S010321002005000200013

57. Lemes MMDD, Bachion MM. Hemodialysis nurses rate nursing diagnoses relevant to clinical practice. Acta Paul Enferm. 2016 Mar/Apr; 29(2):185-90. DOI: 10.1590/1982-0194201600026

58. Fernandes MICD, Bispo MM, Leite EMD, Lopes MVO, Silva VM, Lira ALBC. Diagnostic accuracy of the defining characteristics of the fluid volume diagnosis in hemodialysis patients. Rev Latino-Am Enfermagem. 2015 Nov/Dec; 23(6):1057-64. DOI: 10.1590/0104-1169.0380.2649

59. Tinôco JDS, Paiva MGMN, Lúcio KDB, Pinheiro $\mathrm{RL}$, Macedo BM, Lira ALBC. Complications in patients with chronic renal failure undergoing hemodialysis. Cogitare Enferm. 2017;22(4):e52907. DOI: 10.5380/ce.v22i4.52907 60. Fernandes MICD, Soares CS, Tinôco JDS, 
Delgado MF, Paiva MGMN, Lopes MVO, et al. Excess fluid volume: sociodemographic and clinical analysis in haemodialysis patients. Rev Bras Enferm. 2017 Jan/Feb; 70(1):11-7. DOI: $\underline{10.1590 / 0034-7167-2015-0138}$

\section{Corresponding author}

Micnéias Lacerda Botelho

Email: profmicneias@gmail.com

Submission: 2019/10/03

Accepted: 2019/11/16

Copyright $\odot 2019$ Journal of Nursing UFPE on line/JNOUL.

(cc) EY This is an Open Access article distributed under the terms of the Creative Commons AttributionShareAlike 4.0 International License. This license lets others distribute, remix, tweak, and build upon your work, even commercially, as long as they credit you for the original creation. Recommended for maximum dissemination and use of licensed materials. 